\title{
Assimilation and dissimilation measurements on plankton of Helgoland waters
}

\author{
ERIK Hagmeier \\ Biologische Anstalt Helgoland, Meeresstation, Helgoland
}

\begin{abstract}
KURZFASSUNG: Assimilations- und Dissimilationsmessungen an Plankton aus Helgoländer Gewässern. Im Rahmen der von Professor O. KrNNE angeregten ökologischen Untersuchungen in der Deutschen Bucht wurden Bestands- und Produktionsmessungen am Phytoplankton ausgeführt. Die an der Station "Kabeltonne" (zwischen Helgoland und Düne) in den Monaten Juni 1965 bis August 1966 erhaltenen Meßergebnisse werden dargestellt. Im Winter verhindern Vertikalzirkulation, niedriger Sonnenstand und erhöhter Sestongehalt eine signifikante Assimilationstätigkeit; die Zahl der Plankter war sehr gering. In der Zeit von März bis November wurden verschiedene Perioden mit umfangreichen Phytoplanktonbeständen (bis zu 0,3 mg C/1) und hohen Produktionswerten beobachtet, die hauptsächlich auf der Massenentwicklung einiger weniger Arten beruhen. Das hohe mittlere Verhältnis zwischen Assimilationsleistung und Bestand (4,5:1, gerechnet als C) läßt auf eine sehr gute Nährstoffversorgung schließen. Dem entsprechend ergab die Schätzung der jährlichen Brutto-Primärproduktion bei Helgoland den relativ hohen Wert von $500 \mathrm{~g} \mathrm{C} / \mathrm{m}^{2}$.
\end{abstract}

\section{INTRODUCTION}

The ecological research activities of the Biologische Anstalt Helgoland - initiated by Professor O. KINNE - comprise also measurements of standing stock, assimilation and respiration of plankton organisms in Helgoland waters. The research programme calls for a combination of field observations, experiments in the sea, and laboratory tests (see also TALling 1960). Our work is still in a rather developmental stage and far from giving us a complete picture of what is happening in the surroundings of the island.

\section{METHODS AND RESULTS}

Figure 1 summarizes data obtained in surface waters at the "Kabeltonne", a position located between Helgoland and the "Düne" (Sandy Island). Generally, three samples were taken per week. The curves of temperature, phytoplankton stock, seston, and incoming radiation are based on mean values calculated for 10 days in each case; primary productivity measurements were done less frequently than the other observations. 
E. HagmeIER

HELGOLAND, 54०11.3'N , 7054.0' E (KABELTONNE), 1965/1966

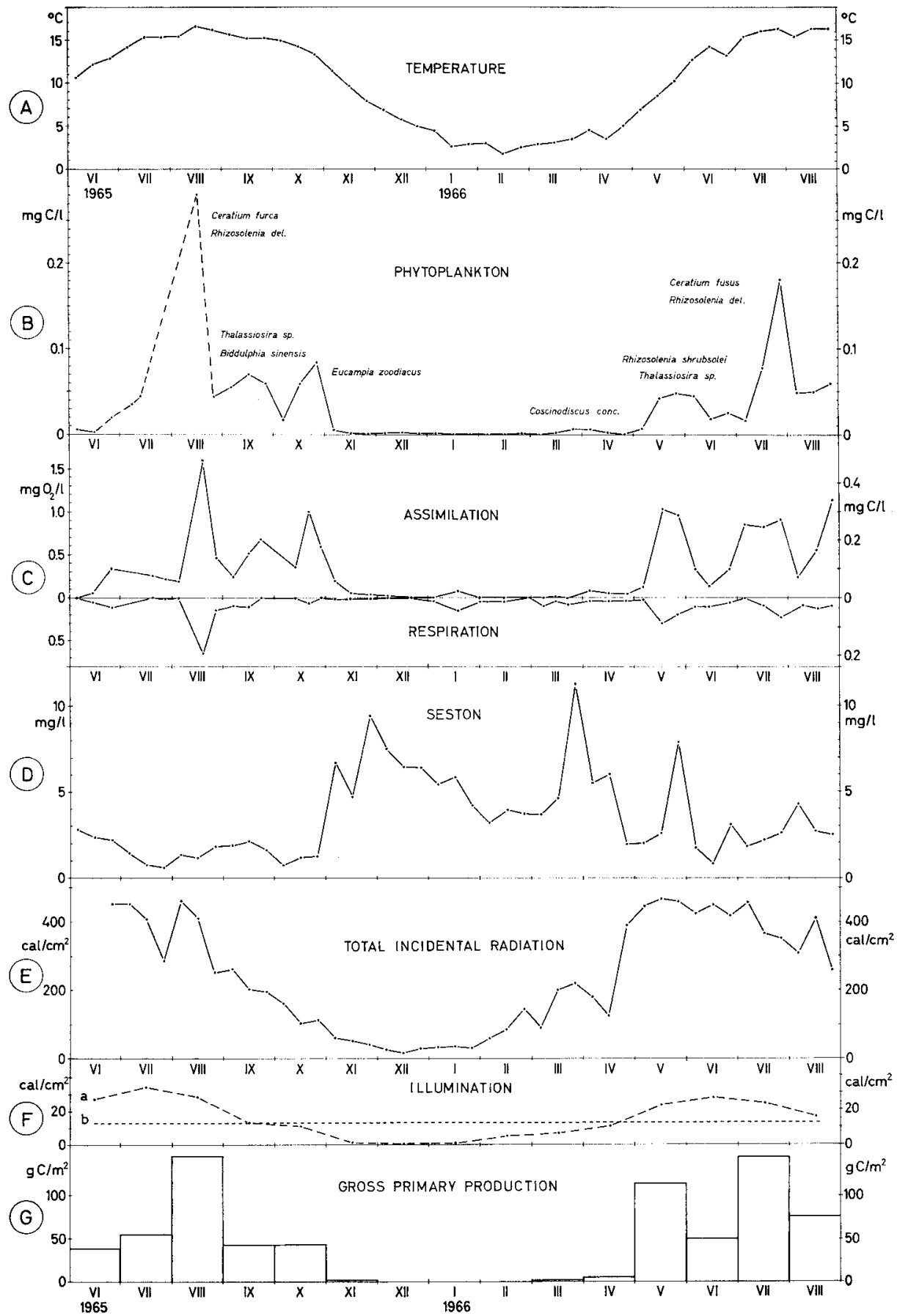


Water temperatures (Fig. $1 \mathrm{~A}$ ) were found to be on an average $0.5^{\circ} \mathrm{C}$ below the 1920 to 1942 mean values reported by GOEDECKE (1954). The decline in October/ December and the subsequent rise in April/June are exceptionally steep.

The standing stock of phytoplankton is assessed in terms of carbon units; these values have not been determined directly, but derived from cell counts and measurements with an inverted microscope. LoHmanN (1908) gave the first examples for the calculation of organic substance in different plankton organisms. A recent publication by Mullin, SLOAN \& EPpley (1966) supports the assumptions made by LoHMANN by chemical analyses.

Two different seasonal periods are to be distinguished (Fig. $1 \mathrm{~B}$ ): a period with a very small population between November and March, and a period comprising the rest of the year with substantial plankton development, resulting in some well defined peaks. Only a few species are dominant during these periods of plankton bloom; especially notable are the large stocks of Ceratium and Rbizosolenia delicatula at the end of July in 1965 and 1966. The subsequent peaks are caused by Biddulphia sinensis. The dominating species (by carbon content) in spring are Rbizosolenia sbrubsolei and Coscinodiscus concinnus. The standing stock, consisting almost exclusively of Eucampia zoodiacus, was a specific phenomenon observed only in 1965 . The data presented by GILlBRICHT (1964) for 1962 and 1963, respectively, demonstrate more variation in regard to composition of plankton and times of maximal development.

Data on gross primary production and respiration (Fig. $1 \mathrm{C}$ ) were obtained by employing the light and dark bottle oxygen method in a laboratory incubator (STEEMANN Nielsen 1963). The bottles were placed on a rotating disc in a water bath at nearly sea temperature for the time being and exposed to a light intensity of 6000 lux for 6 hours (approximately $13 \mathrm{cal} / \mathrm{cm}^{2}$ ). The results may be read as $\mathrm{mg}$ oxygen produced, or, after conversion, in $\mathrm{mg}$ carbon assimilated; the latter expression is less accurate. Respiration values are indicated below the abscissa in Figure $1 \mathrm{C}$.

These productivity data provide some indication as to the activities of the plankton organisms present. Concerning the ratio between standing stock and primary production (Fig. 2) we found a mean of $1: 4.5$ and rather wide variations. The mean value indicates a good nutrient supply. The variations are not irregular: the productivity per unit carbon is mostly high during the depression of the standing stock curve, especially in winter. A relation to the nutrient content of the water is very likely to exist. It is, of course, difficult to eliminate the nutrient influence in order to assess the physiological state of the organisms. A first examination of the results indicates that ceratia are distinctly less active in regard to their rates of photosynthesis than diatoms: a ratio of $1: 4$ was observed!

Fig. 1: Data from surface waters near Helgoland, June 1965 to August 1966. (A) Temperature, mean values for 10 days. (B) Standing stock of phytoplankton, calculated from cell counts and measurements, of three samples per week. (C) Assimilation and respiration of water samples as found in an incubator after exposure to $13 \mathrm{cal} / \mathrm{cm}^{2}$, experiments once a fortnight in winter, twice a week in summer. (D) Seston - dry particulate matter $>1 \mu-$, mean values for 10 days given from 3 samples per week. (E) Total incidental radiation at the sea surface, mean values for ten days from daily registrations. (F) Photosynthetic active light; (a) integral mean values for the surface layer $0-10 \mathrm{~m}$, monthly means, (b) intensity in the incubator experiments. (G) Estimated gross primary production, monthly sums 
There is another factor which determines the productivity results: the population density. In most of our experiments with enriched plankton samples the productivity per unit plankton carbon was found to be lower than in natural concentrations of organisms. This again may be due to the nutrient supply, which - together with the rate of gas exchange between plankton and water - is also strongly influenced by the intensity of water agitation during experiments.

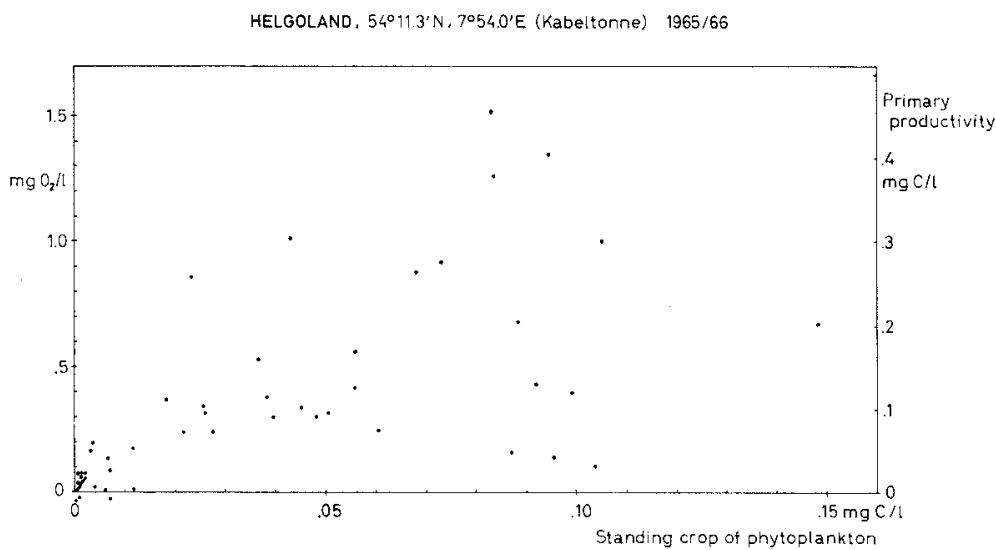

Fig. 2: Standing stock of phytoplankton and gross primary production (from incubator measurements)

From our laboratory experiments and the examples demonstrated by STEEMANN Nielsen in the preceding paper it becomes evident how difficult it is to explore the needs and responses of plankton organisms and to obtain reliable estimations of productivity rates in situ. In principle, productivity studies can be carried out in the sea or under artificial conditions on deck or in the laboratory. When I chose the use of laboratory experiments, it was because I wanted to avoid uncontrolled light conditions, insufficient agitation and technical difficulties when exposing and fetching the bottles at a buoy. Occasionally comparisons were made between in situ and incubator experiments.

My estimations of the productivity in Helgoland waters are thus mainly based upon incubator results; they consider seston content (Fig. $1 \mathrm{D}$ ), incidental radiation at the sea surface (Fig. $1 \mathrm{E}$ ), and occasional light intensity measurements at different depths. For the photosynthetic active part of the radiation (STRICKLAND 1958), Figure $1 \mathrm{~F}$ shows the estimated integral mean intensity in a mixed surface layer of $10 \mathrm{~m}$ depth. By applying the ratio obtained in comparing light intensities under water and in the incubator, the gross primary production data of Figure $1 \mathrm{G}$ have been derived.

During the annual cycle of productivity, two maxima seem to appear, similar to the observations by StemmanN Nielsen (1958) in Danish waters, but the annual sum of carbon assimilated seems to be nearly ten times higher near Helgoland. In winter, 
factors such as vertical circulation, reduced incidental light, and high seston content as a consequence of intensified wind action, cause a halt in productivity. Sometimes seston influence seems to be decisive, as at the end of the Eucampia-bloom in October 1965.

\section{PROPOSED FU'TURE WORK}

For the establishment of exact correlations and for a better understanding of plankton production more data on the relation between seston content and under water light intensities are needed. It must further be considered that - apart from true successions - plankton populations of different water bodies passing the island have been registered. Also, more laboratory experiments are needed to find the reactions of single species under controlled conditions, in line with the work of Talling (1960). Finally, the processing of our net hauls will give us an idea of zooplankton influence on the respiratory rate measured, and the possible grazing effect.

\section{SUMMARY}

1. Data obtained in field observations and laboratory experiments on phytoplankton production as well as on factors important for population dynamics in waters near Helgoland have been reported. All pertinent work was carried out between June 1965 and August 1966.

2. In winter, the rate of assimilation is strongly reduced by vertical circulation, low incoming radiation, and high seston content in the water. Between March and November, mass developments of several species have been recorded.

3. The high mean ratio between assimilation and standing stock of phytoplankton (4.5:1, in carbon units) indicates a good nutrient supply. Accordingly, gross primary production in Helgoland waters is estimated to be about $500 \mathrm{~g} \mathrm{C} / \mathrm{m}^{2}$ year.

\section{ACKNOWLEDGEMENTS}

I am obliged to Mrs. H. Oestreich, Miss. A. Fehse and Miss D. J. Colbourn for careful assistance.

\section{LITERATURE CITED}

Gillaricht, M., 1964. Einwirkung des kalten Winters 1962/63 auf die Phytoplanktonentwicklung bei Helgoland. Helgoländer wiss. Meeresunters, 10, 263-275.

GOEDECKE, E., 1954. Uber Ergebnisse neuerer Untersuchungen der Temperaturverhältnisse in der Deutschen Bucht, Ber. dt. wiss. Kommn. Meeresforsch. 13, 283-297.

Lohman, H., 1908. Untersuchungen zur Feststellung des vollständigen Gehalts des Meeres an Plankton. Wiss. Meeresunters. (Abt. Kiel) 10, 129-370.

Mullin, M. M., Stoan, P. R. \& Eppley, R. W., 1966. Relationship between carbon content, cell volume, and area in phytoplankton. Limnol. Oceanogr. 11, 307-311.

Steemann Nielsen, E., 1958. A survey of recent Danish measurements of the organic productivity in the sea. Rapp. P.-v. Réun. Cons. perm. int. Explor. Mer 144, 92-95. 
- 1963. Productivity, definition and measurement. In: The Sea. Ed. by M. N. Hill. Wiley \& Sons, New York, 2, 129-164.

StrickLAND, J. D. H., 1958. Solar radiation penetrating the ocean. A review of requirements, data and methods of measurement, with particular reference to photosynthetic productivity. J. Fish. Res, Bd Can. 15, 453-493.

Tal.ring, J. F., 1960. Comparative laboratory and field studies of photosynthesis by a marine planktonic diatom. Limnol. Oceanogr. 5, 62-77.

\section{Discussion following the paper by HaGMEIER}

STEEMANN Nielsen: The correlation between carbon in the plankton and the carbon produced during 6 hours a $6 \mathrm{klux}$ showed that about twice as much carbon was produced as found in the cells. This would mean a growth during 6 hours of 1.5 . This is extremely high. Even Chlorella grown at $20^{\circ} \mathrm{C}$ at $6 \mathrm{klux}$ will only double in 6 hours. Is it possible that carbon in the phytoplankton has been underestimated?

HAGMEIER: The carbon content given for the standing stock may indeed be too low in certain cases. The estimations derived from the ideas of LoHMANN seem to be correct in general, as the recent carbon analyses mentioned show. This does not exclude deviations for certain species, which may be decisive for the data given if such a species is dominating. The data should be examined for such possibilities; in the near future we will have an objective means of reexamination employing chemical analyses.

Zertschel: Warum vergleichen Sie die Produktionswerte mit dem Seston und nicht mit dem Detritusgehalt des Wassers? Im Seston ist das Plankton doch enthalten.

Hagmeier: Entscheidend wird in der Tat der Detritusgehalt sein, obwohl das Plankton selbst auch viel zur Trübung besonders der Oberschicht beitragen kann. Uber die Planktonzählungen wird es möglich sein, den Planktonanteil am Seston zu bestimmen und so den Detritusgehalt zu finden; für die vorgelegten Daten habe ich das aber noch nicht getan.

SAVAGE: Concerning the relationship between the drop in primary productivity and the increase in seston, is there any information on the size of the particles which make up the seston? If many of these were relatively large, then they possibly could be sedimented before incubation. This might possibly give an indication of the extent to which primary productivity is reduced because of particulate matter. Do you have any observations?

HAGMEIER: In our incubator experiments the seston has not the same influence as in nature. The bottles are close to the light source, and the light is much less reduced than in the mixed surface layer. The coincidence of productivity reduction and rising seston content is mainly due to the reduction of the standing stock, as many cells decay. The phenomenon you mention is to be considered if we try to estimate the in situ productivity from our incubator results.

HaLIm: Have you considered the possibility of bacterial interference in your oxygen experiments?

HagmeIer: Interference of bacteria with our oxygen experiments is certainly possible. We tried to make it negligible by a thorough cleaning of the bottles and by keeping the duration of the experiments short ( 2 to 6 hours). We did not observe extraordinary respiration in the dark bottles, which would be an indication of bacterial activities.

HaLim: Concerning the difference in productivity between dinoflagellates and diatoms, could you tell us how you reached your conclusions?

HaGmeIER: Firstly, we can compare productivity data from populations, where diatoms or dinoflagellates are dominating; secondly, we currently try to separate certain species in net hauls by sieving them out carefully. The difficulty is that we cannot correct the results according to the physiological state of the organisms. 